\title{
Kanca Indihiang sebagai Embrio Kreativitas Mang Koko
}

\author{
Rasita Satriana ${ }^{1}$ \\ Jurusan Karawitan, Institut Seni Indonesia Surakarta \\ Timbul Haryono, dan Sri Hastanto \\ Sekolah Pascasarjana, Universitas Gadjah Mada Yogyakarta
}

\begin{abstract}
ABSTRAK
Kanca Indihiang adalah sebuah grup yang dibentuk oleh Mang Koko tahun 1946, yang termasuk pada genre seni Jenaka Sunda, yakni seni pertunjukan dengan format seni humor. Kreativitas Mang Koko dalam melakukan berbagai inovasi garap, membuat grup Kanca Indihiang sangat berbeda dengan seni Jenaka Sunda pada umumnya. Nama Mang Koko terkenal sebagai pencipta genre seni baru atau dikenal dengan sebutan karawitan wanda anyar. Untuk mengungkap perkembangan kreativitas Mang Koko, digunakan metode kualitatif dengan pendekatan etnomusikologi. Berdasarkan hasil penelitian dapat disimpulkan bahwa dalam wadah grup Kanca Indihiang, Mang Koko bereksplorasi memodernisasi kekakuan pakem seni kawih Sunda tradisi. Karawitan wanda anyar diyakini sebagai genre karawitan Sunda yang terbentuk dari akumulasi kreativitas berkesenian dari Mang Koko.
\end{abstract}

Kata kunci: Kanca Indihiang, wanda anyar, Mang Koko

\begin{abstract}
Kanca Indibiang: As a Creativity Embryo of Mang Koko. Kanca Indihiang is a group which was first created by Mang Koko in 1946 and is one of the Sundanese art genres that is a performing art with such a humorous art format. Mang Koko's creativity in doing works on a variety of innovations makes Kanca Indihiang group may differ a lot from Sundanese humorous art in general. Mang Koko's name then becomes famous as a creator of a new art genre called 'karawitan wanda anyar'. Thus, a qualitative research applying ethno-musicological approach is done to uncover the development of Mang Koko's creativity. According to this research, it can be concluded that within this Kanca Indihiang group, Mang Koko did some explorations to modernize rigidity in the rules of traditional Sundanese kawih. Karawitan wanda anyar is believed as a Sundanese karawitan genre shaped from the accumulation of Mang Koko's artistic creativities.
\end{abstract}

Keywords: Kanca Indihiang, wanda anyar, Mang Koko

\section{Pendahuluan}

Mang Koko adalah sosok seniman generasi kedua setelah Raden Mahyar Angga Koesoemadinata dalam sejarah perkembangan karawitan Sunda era abad XX. Ia juga dinobatkan sebagai tokoh pembaharu karawitan Sunda dengan kekaryaannya yang sangat beragam. Hal ini ditandai dengan piagam anugerah seni dari negara melalui Menteri Pendidikan dan Kebudayaan Republik Indonesia sebagai Pembaru dalam Seni Karawitan Sunda yang diterimanya tahun 1971. Pembaruan karawitan
Sunda yang dilakukan oleh Mang Koko meliputi ranah sekar (lagu vokal) dan gending (intrumental). Lagu vokal yang dikembangkan oleh Mang Koko adalah lagu vokal yang bermetrum tetap yang dalam khasanah karawitan Sunda disebut dengan istilah kawih. Adapun dalam ranah gending, Mang Koko mengembangkan waditra (instrumen) kacapi dan gamelan pelog salendro (perangkat gamelan Sunda yang berlaras pelog dan slendro) baik dalam hal teknik tabuhan maupun pengolahan komposisinya. Keunikan atau kekhasan garapan karawitan yang dikembangkannya, kemudian mewujud menjadi

\footnotetext{
1 Alamat korespondensi: Program Studi Pengkajian Seni Pertunjukan dan Seni Rupa-UGM, Gedung Lengkung, Jln. Teknika Utara, Pugung, Yogyakarta HP. 0817257436. E-mail: rasitasatriana@yahoo.com
} 
gaya pribadi yang memunculkan beberapa istilah seperti: Kawih Mang Kokoan, Kacapian Mang Koko, dan gamelan wanda anyar.

Istilah gamelan wanda anyar muncul ketika Mang Koko menggarap sekar gending dalam gamelan pelog salendro yang jauh berbeda dengan garap sekar gending kiliningan tradisi Sunda yang sama-sama menggunakan perangkat gamelan pelog salendro. Revolusi garap gamelan yang dilakukan oleh Mang Koko menimbulkan reaksi penolakan dari kalangan seniman tradisi. Mereka memvonis Mang Koko telah melanggar bahkan merusak pakem tradisi seni kiliningan Sunda. Begitu tersakitinya hati para seniman tradisi akan kehadiran karya gamelan Mang Koko (gamelan wanda anyar). Menurut Hawe Setiawan (2004), mereka menyebutnya sebagai gamelan brangbrengbrong dan bahkan ada yang tega menyebutnya dengan gamelan beatle (plesetan dari The Beatles grup band asal Inggris yang saat itu sangat digandrungi kawula muda Bandung). Ini sebagai bukti penilaian mereka (seniman tradisi) pada karya gamelan Mang Koko yang disamakan dengan musik band yang brangbrengbrong (ribut, berisik) yang tidak menjunjung tinggi nilai-nilai adiluhung karawitan Sunda tradisi.

Tidak hanya sampai disitu, salah seorang birokrat ketua Badan Kesenian Sunda (BKS), sebuah lembaga seni yang ada di Bandung, mengajukan protes kepada Konservatori Karawitan (Kokar) Bandung di tahun 1960-an. Masalah yang disoroti fihak BKS adalah program pengajaran gamelan yang dilakukan oleh Konservatori Karawitan (Kokar) Bandung terkait dengan munculnya gamelan wanda anyar yang dianggap sebagai produk lembaga pendidikan ini. Hal tersebut dapat dimengerti, karena waktu itu Mang Koko merupakan salah seorang pengajar di Konservatori Karawitan (Kokar) Bandung yang mengajar gamelan dan titi laras, bahkan menjadi direkturnya mulai tahun 1965 sampai tahun 1972. Di Kokar inilah Mang Koko lebih banyak kesempatan untuk mengembangkan kreativitasnya dalam gamelan pelog salendro, karena lembaga ini difasilitasi dengan perangkat gamelan lengkap yang khusus didatangkan dari Jawa Tengah. Gamelan wanda anyar lambat laun diakui sebagai salah satu perkembangan garap gamelan Sunda yang disenangi terutama kalangan generasi muda. Selanjutnya istilah wanda anyar digunakan sebagai penanda kreativitas Mang Koko dalam karawitan Sunda.

Karawitan wanda anyar sebagai salah satu genre karawitan Sunda karya Mang Koko yang mengalami puncak kepopuleran di tahun 1970an tidak muncul secara tiba-tiba, tetapi melalui tahap-tahap proses kreasi yang sangat panjang. Sebelum merambah pada jenis komposisi gamelan yang dikenal dengan sebutan gamelan wanda anyar, terlebih dahulu Mang Koko berkreasi dalam waditra kacapi (kacapi) sehingga memunculkan sebutan kacapian Mang Koko. Ketika kacapian Mang Koko digunakan sebagai ansambel pengiring lagu-lagu khas Mang Koko, muncul sebutan Kawih Mang Kokoan yang kekhasannya meliputi garap waditra dan komposisi iringan. Eksplorasi petikan kacapi dan vokal kawih, telah dimulai oleh Mang Koko sejak tahun 1946 bersama grup Kanca Indihiang. Dengan demikian, dapat dikatakan bahwa kekaryaan Mang Koko dalam karawitan Sunda berawal dari eksplorasinya bersama grup Kanca Indihiang.

Berdasar pada asumsi bahwa kreativitas Mang Koko dalam karawitan Sunda berawal dari eksplorasinya bersama grup Kanca Indihiang, maka untuk pembuktiannya harus dimulai dengan bahasan proses kerja yang dilakukan Mang Koko bersama Kanca Indihiang. Kanca Indihiang adalah sebuah grup yang dibentuk Mang Koko dengan format seni humor yang mengedepankan garapan seni vokal kawih dengan waditra pokok kacapi, rebab, dan suling. Dalam khasanah seni Sunda, format ini dikenal dengan sebutan seni Jenaka Sunda.

\section{Jenaka Sunda}

Kesenian Jenaka Sunda merupakan kesenian bentukan baru dalam khasanah seni pertunjukan Sunda. Seni ini termasuk ke dalam rumpun seni hiburan. Menurut ensiklopedi Sunda, Jenaka Sunda atau Janaka Sunda adalah permainan kacapi yang dibarengi dengan lawakan. Petikan-petikannya tidak berpatokan, baik irama maupun gendingnya, berbeda dengan gamelan dan Tembang Sunda (Rosidi, 2000: 201). Pada dasarnya petikan-petikan kacapi dalam seni Jenaka Sunda lebih ditonjolkan 
unsur humornya, tidak mengacu pada gaya petikan yang sudah ada seperti Celempungan dan Tembang Sunda Cianjuran. Petikan kacapi Jenaka Sunda menurut istilah Maman SWP disebut dengan istilah petikan kacapi warung kopi, yaitu petikan kalangenan (manasuka) yang disajikan menurut potensi si pemetiknya. Biasanya pemain membuat petikan-petikan yang lucu di antaranya mengadaptasi tabuhan kendang yang dilafalkan seperti: $d u$ lang katincak, tumpak mobil butut, domba nini kencar kencarkeun, cir gobang gocir, dan sebagainya (wawancara tanggal 4 Oktober 2011 di Bandung).

Pencipta seni Janaka Sunda adalah Menir Muda alias Holil sekitar tahun 1930-an (Sudarsono, 1991: 13; Rosidi, 2000: 201). Seni ini mengandalkan olah vokal dengan nada-nada tinggi. Unsur humor dimunculkan antara lain dengan mengeksploitasi lagu melalui senggolsenggol yang dapat menimbulkan kesan lucu, atau dialog lucu yang sengaja dimunculkan di antara penyajian lagu-lagunya. Adapun jenis kawih yang digunakan dalam seni Jenaka Sunda adalah kawih kepesindenan yang menurut Suaman (Sudarsono, 1991: 4) liriknya biasanya menggunakan sisindiran, yaitu salah satu jenis sastra Sunda lama yang biasa dijadikan pola lirik lagu kawih tradisi.

Cikal bakal Jenaka Sunda mulai mucul ketika di Bandung didirikan stasiun Radio. Menurut Suadi (Durban Arjo, 2011: 406), Bobodoran Sunda mulai menggegerkan pendengar radio NIROM dengan munculnya grup Reog Menir dari Sukabumi dan Menir Muda alias Holil dari Bandung. Holil yang hanya dengan iringan kacapi yang dipetiknya sendiri, berhasil memikat pendengar radio NIROM tahun 1938 dengan menyajikan lagu-lagu kocak, dan ternyata kepopulerannya mengungguli grup Reog Menir Sukabumi. Saingan Holil pada waktu itu adalah Epen Sutardi pimpinan kacapi orkes Pangluyu bersama juru sinden Nyi Mas Sutirah alias Nyi Mas Pangluyu.

Berdasarkan pernyataan Suadi tersebut dapat disimpulkan bahwa seni Jenaka Sunda yang selanjutnya berkembang dengan waditra pokok kacapi, adalah perkembangan dari acara radio yang berjudul Bobodoran Sunda yang awalnya diisi oleh grup Reog dan kacapi Orkes. Berkat kepopuleran nama Holil alias Menir Muda, masyarakat mengakuinya sebagai pencipta genre seni humor dengan nama Janaka Sunda yang lebih dikenal dengan sebutan seni Jenaka Sunda. Pada waktu itu muncul juga kelompok Epen Sutardi dari grup kacapi orkes, maka pembentukan ensambel seni Jenaka Sunda mengacu pada dua grup tersebut. Akhirnya muncullah seni Jenaka Sunda dengan spesifikasi musik vokal dengan iringan kacapi sebagai waditra pokok yang ditambah dengan waditra pendukung sesuai dengan kapasitas kekuatan grup. Maka muncul grup-grup Jenaka Sunda dengan waditra yang berbeda-beda. Ada yang hanya menggunakan satu waditra kacapi saja, dan ada pula grup dengan ensambel kacapi yang lebih lengkap seperti kacapi orkes jaman tahun 1930-an (Gambar 1).

Gambar 1 menunjukkan bahwa pada zaman Radio NIROM telah banyak kelompok seni Jenaka Sunda dengan beragam waditranya. Tampak dalam gambar, waditra yang mereka gunakan meliputi biola, gitar, dan kendang selain kacapi parahu sebagai istrumen pokoknya. Kelompok tersebut kemungkinan berkaitan dengan Epen Sutardi pimpinan kelompok kacapi orkes Pangluyu yang sekitar tahun 1938 merupakan saingan Holil dari jenaka Sunda Menir Muda dalam hal bobodoran. Suadi (Durban Arjo, 2011: 406) menyebutnya sebagai bobodoran Sunda, yang kalau diterjemahkan dalam bahasa Indonesia artinya sama dengan Jenaka Sunda. Entah kapan istilah bobodoran Sunda tersebut berganti nama menjadi Jenaka Sunda, sampai tulisan ini dibuat belum ditemukan data tentang hal tersebut.

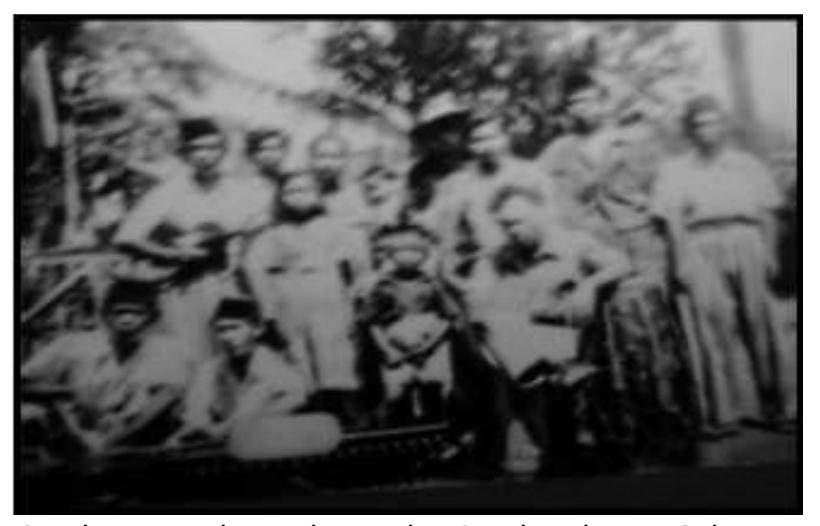

Gambar 1. Kelompok Jenaka Sunda Ahrum Subarma yang lebih terkenal dengan nama Epen Saputra yang eksis pada zaman Radio NIROM.

(Photo koleksi: Nendy Subagja). 


\section{Kanca Indihiang}

Pada tahun 1946, Mang Koko mendirikan grup Sekar Jenaka yang diberi nama Kanca Indihiang. Saat inilah sebenarnya sebagai titik tolak keberangkatan Mang Koko pada kreativitas di bidang karawitan Sunda yang sudah lama ditinggalkannya. Mang Koko sudah mahir memainkan kacapi tradisi sejak usia 10 tahun, namun ketika mulai sekolah di HIS kegiatan berkeseniannya beralih pada musik Barat sehingga ia dikenal sebagai pemain gitar nomor satu di lingkungan sekolahnya. Pergaulan semasa sekolah di HIS sampai lulus dari MULO tahun 1936, mengubah karakter pribadi Mang Koko menjadi sosok manusia kosmopolit yang modern.

Semasa di MULO, Mang Koko juga mengikuti kursus mengetik, sehingga ia mengantongi sertifikat mengetik tingkat mahir dengan teknik sepuluh jari dari KEOM. KEOM adalah sebuah lembaga keterampilan jaman Belanda yang mengadakan kursus-kursus seperti bond A dan bond B untuk pegawai perkantoran. Menurut penuturan Bambang Arayana Sambas (seorang budayawan Sunda) Mang Koko mengikuti kursus mengetik dari lembaga tersebut, sehingga lulus dari MULO dilengkapi pula dengan sertifikat mengetik mahir (wawancara tanggal 13 Mei 2013 di Bandung). Dapat diasumsikan bahwa keterampilan tangan dalam hal mengetik tersebut sangat menunjang dalam memainkan waditra gitar maupun kacapi. Menurut Tatang Benyamin Koswara, keterampilan mengetik sepuluh jari yang dimiliki Mang Koko menghasilkan istilah petikan kacapi sepuluh jari sebagai gaya petikan kacapi Mang Koko (wawancara tanggal 18 Juni 2010 di Bandung).

Ketika Mang Koko bermukim di kota Bandung tahun 1939, pengaruh kota metropolitan semakin membentuk pribadinya, termasuk dalam bermusik seperti pengakuannya yang ditegaskan pula oleh beberapa koleganya bahwa selama di Bandung kegiatan berkesenian Mang Koko adalah musik Barat. Hal ini dapat dibuktikan oleh bergabungnya Mang Koko dengan The Yop Hawaian Band dan turut serta pula dengan grup Stek Orkes sebagai pemain gitar. Kalaupun ia masih menggeluti waditra kacapi, tetapi saat itu kacapinya telah distem dengan tangga nada diatonis untuk mengiringi lagu-lagu melayu dan pop barat.
Hal tersebut dijalaninya sampai Jepang masuk Indonesia tahun 1942 (Durban Arjo, 2011: 406).

Pengalaman bekerja di media masa sangat berperan dalam pembentukan karakter diri Mang Koko, naluri jurnalistiknya yang kritis membentuk pribadi yang sangat peduli pada lingkungan di mana ia tinggal. Pengalaman tersebut menjadi bekal pengetahuan Mang Koko dalam menanggapi fenomena yang terjadi dalam masyarakat. Seperti dijelaskan Borchert (Sunarto, 2010: 418) bahwa pengalaman adalah suatu dasar atau titik pijak dalam pembentukan pengetahuan, sesuai dengan doktrin empirisme bahwa sumber pengetahuan harus dicari dari pengalaman. Justru pengalaman bermain musik Barat, merupakan bekal pengetahuan yang lebih memberi warna pada karya-karya Mang Koko. Nano Suratno menegaskan bahwa yang membedakan Mang Koko dengan pencipta lagu kawih Sunda yang lain adalah bekal pengalamannya dalam musik Barat, dan itu sangat mewarnai karya-karyanya.

Ketika Mang Koko mengungsi ke Indihiang awal tahun 1946, memorinya kembali pada saat ia memainkan kacapi sambil melantunkan lagu Balon Ragrag kesenangannya. Apalagi ia sering mendengar siaran radio yang menyajikan kesenian Jenaka Sunda, yang secara kualitas baik vokal maupun kacapinya tidak lebih bagus darinya. Fenomena tersebut membuat Mang Koko gelisah. Kegelisahan merupakan salah satu ciri orang kreatif ketika menanggapi suatu fenomena yang tidak sesuai dengan hati dan pikirannya. Sifat kritisnya senantiasa mengusai pikirannya untuk mengubah situasi kemapanan seni tradisi Jenaka Sunda yang didengarnya.

Sebagai orang modern yang dikaruniai kemampuan otak jenius dan keterampilan motorik lebih dari orang kebanyakan, mindset-nya selalu ingin berbuat sesuatu yang berbeda dengan orang lain. Dalam berkesenian pun ia bekerja pada lahan yang tidak dikerjakan orang lain, misalnya, tertarik dengan seni Jenaka Sunda, tetapi seni Jenaka Sunda yang dibuatnya berbeda dengan yang ada waktu itu. Itulah sikap Mang Koko dalam mengkritisi seni tradisi, dalam pandangannya seni tradisi harus dikembangkan. Suatu sikap dinamis sebagai gambaran orang modern, yakni selalu 
menginginkan hal-hal baru yang tidak dikerjakan orang lain. Sifat kritis Mang Koko tersebut sesuai dengan pernyataan Waridi (2005: 543) bahwa salah satu ciri seorang inovator adalah tidak puas terhadap sesuatu yang telah ada, sehingga memacu untuk melahirkan sesuatu yang baru.

Kepeloporan Mang Koko dalam mengkritisi seni Jenaka Sunda sifatnya menyeluruh, mulai dari alat yang digunakan, lagu-lagu yang disajikan sampai pada teknik penyajiannya. Pada segi waditra, Mang Koko memilih menggunakan kacapi siter yang sudah biasa ia kembangkan sewaktu menggarap kacapi modern. Lebih praktis apabila dibandingkan dengan kacapi parahu yang biasa digunakan oleh kelompok Jenaka Sunda yang lain pada waktu itu. Untuk kelengkapan waditranya ia memilih suling dan rebab. Mengapa pilihannya jatuh pada rebab, dan tidak pada biola yang sudah dikenalnya sejak kecil, padahal ketika di MULO Mang Koko terkenal sebagai pemain biola yang handal? Alasannya mudah ditebak, Mang Koko berkecimpung dalam musik Barat sudah sejak remaja. Ketika sudah menginjak masa dewasa, ia bergabung dengan band dan stek orkes. Perhatian Mang Koko kembali pada kesenian Sunda. Mang Koko ingin mencurahkan segenap ide dan pikirannya pada kesenian Sunda secara total. Memodernisasikan kesenian Sunda dimulai dengan pemberdayaan alat-alat tradisi Sunda, dan itu dilakukannya sepanjang perjalanan kariernya dalam berkesenian.

Mang Koko dalam perjalanan kariernya mengolah karawitan Sunda dengan sentuhan garap seni moderen, sehingga tahun 1960-an dicemooh sebagai komponis gamelan beatle yang dapat dimaknai bahwa karya-karyanya berbau pop. Namun, mengenai penggunaan waditra tetap mempertahankan keaslian waditra karawitan Sunda. Hal tersebut dilakukan sepanjang perjalanan kariernya sebagai komponis, walau tema kekaryaannya tidak terbatas pada karawitan Sunda. Seperti ketika menggarap gending karesmen Nyai Dasima yang menggunakan seting budaya Betawi, penggarapan karawitannya full menggunakan gamelan pelog slendro. Hal tersebut sudah dimulai dari pertama kali terjun kembali pada karawitan Sunda, yakni ketika membentuk sekar jenaka Kanca Indihiang.
Salah satu dari kepeloporan Mang Koko dalam mengkritisi seni tradisi diawali dengan memodernisasikan petikan kacapi. Berbekal pengalaman sebagai pemain gitar dan pemain kacapi modern yang dikembangkannya, Mang Koko mengemas petikan kacapi Pantun yang digabungkan dengan petikan baru hasil adaptasi dari petikan gitar. Petikan baru tersebut memberdayakan tangan kanan yang membunyikan tiga nada secara bersamaan sehingga menimbulkan seperti bunyi akoord pada musik Barat, sementara tangan kiri difungsikan sebagai bas. Dengan gaya petikan tersebut, irama menjadi gagah seperti lagu mars karena hitungan genap setiap matranya diisi petikan bas yang membunyikan nada kenongan, terkesan seperti irama golempang pada seni kendang pencak. Teknik petikan kacapi seperti itu kemudian dikenal sebagai petikan dijambret atau teknik petikan dikemprang menurut istilah Tatang Benyamin Koswara. Apabila dituliskan, teknik petikan dijambret tersebut terlihat seperti pada contoh notasi gambar 3 .

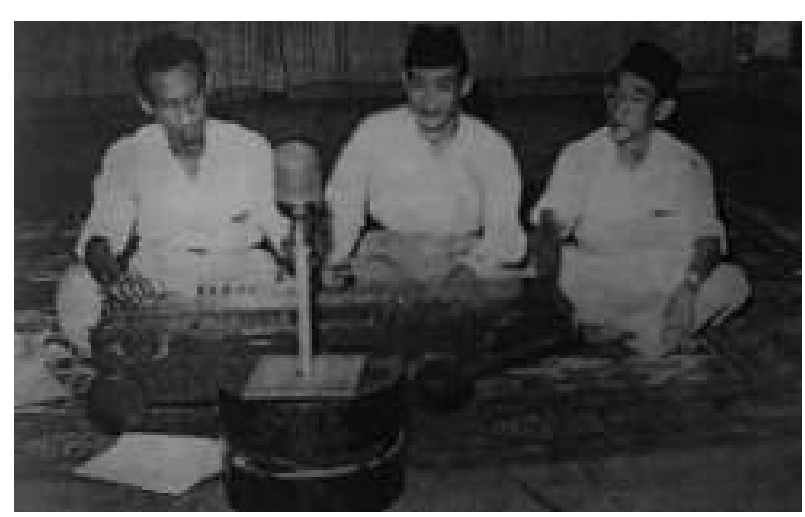

Gambar 2. Kanca Indihiang sedang siaran di RRI Bandung tahun 1950-an. Mang Koko sebagai vokalis merangkap pemain kacapi, yang di tengah adalah pemain suling merangkap vokal, sedang pemain rebab tidak tampak dalam gambar. (Photo koleksi Suadi).

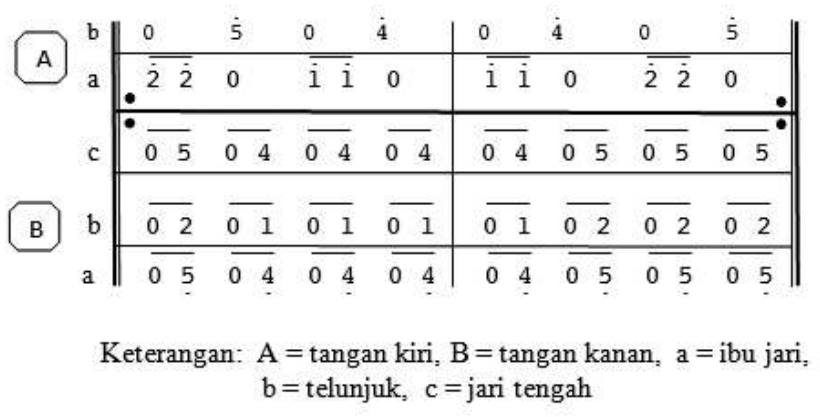

Gambar 3. Teknik petikan dijambret atau dikemprang 
Petikan kacapi gambar 3 merupakan salah satu pembaruan yang dilakukan oleh Mang Koko pada zaman Kanca Indihiang sebagai usaha mendinamisasikan petikan kacapi dari sekedar petikan warung kopi seperti yang biasa dilakukan oleh grup Jenaka Sunda pada waktu itu. Maman SWP menyebut petikan tersebut dengan istilah petikan chorda block, meminjam dari istilah musik Barat. Menurutnya, petikan tersebut mirip dengan tabuhan piano, yakni tangan kanan membunyikan akoord tiga nada dan tangan kiri membunyikan dua nada sebagai bas, besar kemungkinannya Mang Koko mengaplikasikan tabuhan piano pada petikan kacapi (wawancara tanggal 4 Oktober 2011). Aplikasi teknik petikan dijambret pada pola pirigan (iringan) mengacu pada pola kenongan lagu. Mang Koko mengkombinasikan petikan dijambret tersebut dengan petikan kacapi tradisi yang biasa disebut dengan teknik dijeungkalan dari teknik petikan kacapi Celempungan dan teknik sintreuk toel dari teknik petikan kacapi Cianjuran.

Mengenai lagu-lagu yang disajikan, Mang Koko tidak mau membawakan lagu-lagu kawih kepesindenan tradisi yang sudah ada, baik dari sejak (gaya) kiliningan maupun sejak ketuk tilu seperti yang disajikan oleh kelompok Jenaka Sunda pada umumnya. Mang Koko membuat lagu sendiri dengan format yang lebih dinamis, disesuaikan dengan rumpaka (teks lagu) yang dibuatnya sesuai dengan situasi lingkungan pada waktu itu. Apabila dilihat dari segi bentuk gending, lagu-lagu ciptaan Mang Koko masih mengacu pada bentuk gending tradisi, terutama pola-pola gending bentuk renggong alit (bentuk gending kecil) yang memiliki pola baku. Pola-pola tersebut tidak disikapi sebagai pola baku sehingga dalam aplikasinya Mang Koko menciptakan lagu-lagu yang berpola campuran menurut pakem tradisi, atau sebagian lagu berpola tradisi dan bagian selanjutnya berpola bebas.

Secara melodi, lagu-lagu Mang Koko dalam sekar jenaka ini lebih sederhana dari lagu kiliningan tradisi yang biasa disajikan oleh para pesinden. Kesederhanaan tersebut terkait dengan pemilihan irama atau tempo lagu yang cenderung lebih cepat dari sajian kiliningan tradisi. Mang Koko menggunakan irama sawilet dengan tempo atau laya sedang dan gandang (semangat), sehingga vokalis tidak memiliki kesempatan dan ruang untuk mengolah senggol (variasi melodi lagu) sebagaimana pada sajian kiliningan tradisi. Adapun model lagu-lagu Kanca Indihiang yang merupakan format baru dalam khasanah lagu kawih Sunda, seperti dapat dilihat pada contoh Lagu Jangkrik.

$\underline{\text { Jangkrik}}$, laras $=$ selendro, gerakan $=$ gandang $($ notasi damina $)$

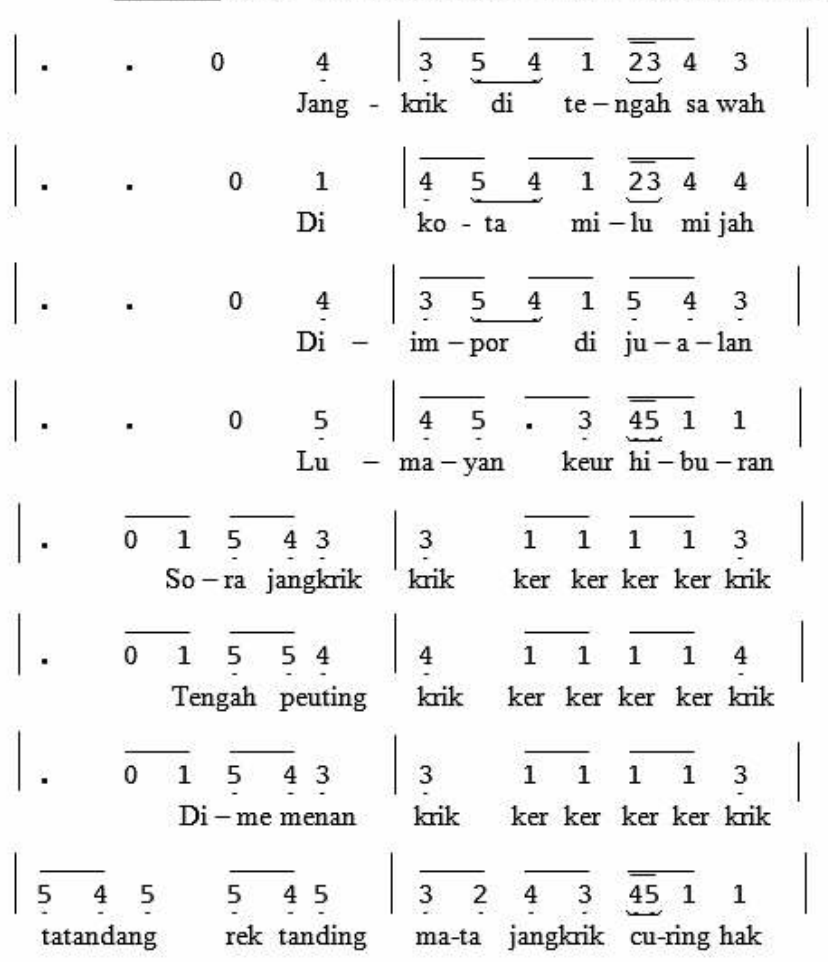

Melodi lagu karya Mang Koko lebih sederhana bila dibanding dengan kawih kepesindenan, dengan penggunaan kebanyakan satu nada atau paling banyak dua nada dalam satu suku kata. Hal ini menimbulkan kesan gembira, apalagi dengan irama gandang yang dapat diartikan lebih cepat dari orang berjalan, lebih mendekati pada irama mars dalam musik Barat. Penggunaan petikan kacapi dijambret menambah kesan dinamis dan gagah dengan laras salendro.

Kontur melodi yang dipilih Mang Koko membuat lagu menjadi lebih bergairah, dinamis dengan pola garis melodi zigzag yang sering digunakan. Seperti dapat dilihat pada melodi baris pertama lagu Jangkrik di atas, garis melodi ini menimbulkan kesan hidup, dinamis, tidak melismatik yang menimbulkan kesan mendayudayu. Tanpa lirik pun kesan melodi ini sudah menampakkan rasa ceria. Melodi tersebut tidak akan cocok apabila diberi lirik misalnya naha 
engkang bet cidra (kenapa kanda ingkar janji), lirik tersebut berjiwa penyesalan, lebih cocok menggunakan melodi yang melismatik dengan laras pelog atau madenda.

Selain pola melodi zigzag, Mang Koko juga menerapkan pola melodi melompat di samping pola melodi berjalan. Pola melodi berjalan adalah melodi dengan nada-nada yang berurutan baik naik maupun turun, seperti pada matra pertama baris kelima dan matra pertama baris ketujuh pada lagu Jangkrik di atas. Adapun melodi melompat adalah melodi dengan nada yang tidak berurutan, melewati satu nada atau lebih. Pada lagu Jangkrik di atas terdapat melodi melompat dengan swarantara (interval) adu laras yakni melewati satu nada seperti pada matra kedua baris kelima dan baris ketujuh, dari nada $4(t i)$ ke nada $1(d a)$ adalah berjarak $a d u$ laras. Lompatan berjarak kempyung juga digunakan, yaitu nada yang melompati dua nada seperti pada melodi matra kedua baris keenam lagu Jangkrik di atas.

Di balik kesederhanaan melodi dari lagu-lagu Kanca Indihiang, Mang Koko mengemas sajiannya dengan garapan baru yang lebih menarik. Garap sajian lagu-lagu Kanca Indihiang selain dengan anggana sekar (vokal tunggal), juga disajikan dengan rampak sekar (vokal bersama) baik satu tahapan swara maupun lebih, serta bentuk dialog antara vokal tunggal dan vokal rampak. Kebanyakan dalam satu lagu disajikan dengan berbagai garap, misalnya vokal tunggal dilanjutkan rampak seperti pada lagu: Batik, Beus kota, Katumbiri, Kulu-kulu kombinasi, Roda malem, dan Jaman Atom. Di dalam garap rampak, ada yang satu tahapan swara ada juga yang model layeutan swara (paduan swara), seperti pada lagu: Beus kota, Jaman Atom, Jangkrik, Maen bal, Hayam Jago, Urang Kampung, dan Tukang Beca. Selain itu ada juga lagu yang digarap dialog antara vokal tunggal dan vokal rampak, seperti pada lagu: Jaman Atom, Badminton, Jangkrik, Katumbiri, Hayam Jago, Buruh Leutik, dan Tukang Beca.

Garap layeutan swara dalam khasanah kawih Sunda merupakan hal baru yang belum pernah dilakukan oleh seniman lain sebelum Mang Koko. Walaupun konsepnya sudah dibuat oleh Raden Mahyar Koesoemadinata, namun aplikasinya belum direalisasikan secara sempurna.
Hal tersebut dapat dimaklumi, karena Machyar lebih berkonsentrasi pada bidang konsep-konsep dalam karawitan Sunda. Di dalam kekaryaan lagu dan gending, dia lebih banyak mentranskrip gending-gending Sunda klasik yang hampir punah dalam memanfaatkan serat kanayagan daminatila. Sehingga aplikasi konsep yang dia buat belum semuanya terealisasikan dengan baik, termasuk konsep pralagam yang kemudian menjadi konsep layeutan swara. Mang Koko bersama grup Kanca Indihiang telah mengaplikasikan konsep tersebut berupa layeutan swara yang terdiri atas tiga tahapan swara, seperti pada notasi cuplikan lagu Maen Bal.

Maen BaL, Madenda 4 =Tugu (notasi damina)

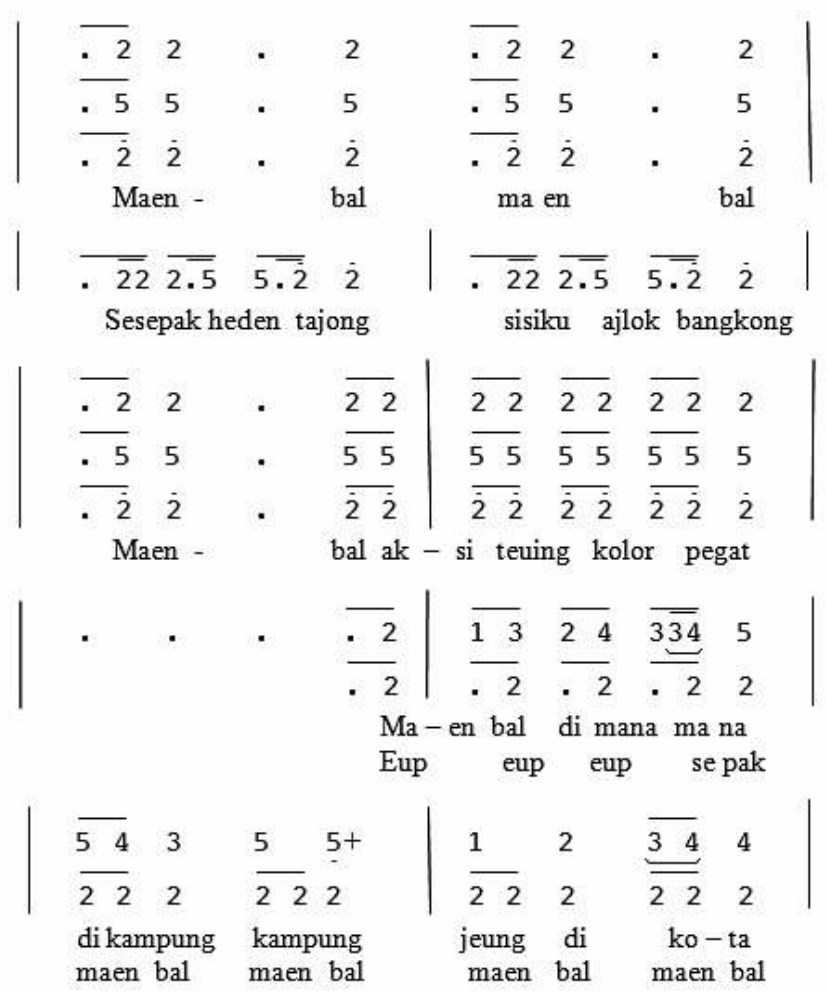

Apabila dilihat dari segi irama, hampir semua lagu-lagu Mang Koko dalam sekar jenaka dalam bentuk gending irama sawilet. Irama sawilet berarti dalam satu gongannya terdiri atas empat matra, dan satu matra terdiri atas empat ketukan (Periksa Koesoemadinata; Irawan, 2003; Rustandi, 2005). Gerakan atau laya yang digunakan kebanyakan sedang dan gandang (semangat). Di dalam satu kaset rekaman yang berisi delapan belas lagu, hanya dua lagu yang berirama sawilet rangkep yaitu lagu Kulu-kulu kombinasi dan Kajaksan. Dari judul lagunya yang menggunakan nama gending tradisi, 
lagu ini dibuat berdasarkan gendingnya yang dalam istilah tradisi disebut ngalaguan gending (memberi melodi pada gending yang sudah ada) seperti lagulagu kawih kepesindenan dalam irama ini.

Lagu-lagu Mang Koko dalam sekar jenaka Kanca Indihiang adalah genre seni humor, kesan itulah yang secara terang-terangan ditonjolkan sebagai medium. Kendati demikian, nilai ekstrinsik yang disampaikan beragam tema, sesuai dengan bagaimana Mang Koko merepresentasikan fenomena yang diserap dari lingkungannya. Mang Koko tidak bermaksud membuat reportase berdasarkan laporan pandangan mata pada lagu Jangkrik di atas, seperti pernyataan Sumardjo (2000) bahwa dengan karyanya seorang seniman menyampaikan nilai dan norma seperti harapan masyarakatnya. Pada kurun waktu tertentu, masyarakat Sunda pernah terjangkiti permainan adu jengkerik. Akan tetapi bukan adu jengkeriknya yang ingin disampaikan oleh Mang Koko selaku seniman, namun nilai atau norma yang menjadi gambaran harapan atau cita-cita masyarakat.

Selain dari segi musikal, Mang Koko juga membongkar kekakuan pakem rumpaka (teks lagu) yang masa itu digunakan oleh para pencipta lagu. Mang Koko memelopori penggunaan rumpaka yang tidak menganut pada aturan puisi Sunda lama seperti pupuh dan sisindiran. Pupuh adalah puisi Jawa yang berasal dari sastra lama yang terikat oleh jumlah baris tiap bait, jumlah suku kata dalam tiap baris (guru wilangan), dan bunyi vokal akhir dari tiap baris (guru lagu) (Solihin, 2012: 9-11; Soepandi, 1988: 165). Adapun sisindiran adalah puisi Sunda lama semacam bahasa ikatan seperti halnya pupuh, termasuk pada jenis ini adalah rarakitan, paparikan, dan wawangsalan. Mang Koko tidak menggunakan teks lagu yang mengacu pada puisi Sunda lama tersebut. Teks lagu yang dibuat Mang Koko lebih dekat pada puisi bebas, yang saat itu belum dilakukan oleh para penggurit rumpaka untuk lagu-lagu kawih Sunda.

Rumpaka lagu-lagu Mang Koko dalam genre sekar jenaka tersebar dalam berbagai tema. Hal tersebut tercipta atas dasar sikap kritisnya pada lingkungan di mana ia tinggal dan bergaul. Coba kita perhatikan sekali lagi cuplikan teks lagu Jangkrik berikut ini.
Jangkrik di tengah sawah,

di kota milu mijah,

diimport dijualan,

lumayan keur hiburan.

Sora jangkrik, krik ker ker ker ker krik,

tengah peuting, krik ker ker ker ker krik,

dimemenan krik, ker ker ker ker krik,

rek tandang rek tanding,

mata jangkrik curinghak.

Ngala jangkrik di sawah, peuting waktuna ceuyah,

iasruk didamaran,

ditewak dikundangan.

Ngala jangkrik bari dioboran, tengah sawah bari digebrigan, ting pucunghul tina daun sengang, diudag ditewak leuh horeng teh gaang.

(Jengkerik di tengah sawah, di kota turut bertingkah, diimport untuk dijual, Lumayan untuk hiburan, Suara jengkerik, krik ker ker ker ker krik, tengah malam, krik ker ker ker ker krik, dimanjakan, krik ker ker ker ker krik, akan berlaga, bertanding, mata jengkerik membelalak.

Mencari jengkerik di sawah, banyak diwaktu malam, dicari menggunakan lampu, ditangkap disimpan di tempat aman.

Mencari jengkerik pakai lampu, di sawah sambil ditakut-takuti, pada keluar dari balik daun sengang, dikejar, ditangkap...padahal gaang.)

Berdasarkan jenisnya, lirik tersebut di atas menurut Adisastra (1984: 69) termasuk pada jenis puisi ranggeuyan. Ranggeuyan yang digunakan termasuk bentuk opat ranggeuyan (empat serangkai), dimana pada tiap baitnya terdiri atas empat baris. Sementara Sukanda, dkk. (1985: 64) menyebut lirik semacam ini dengan istilah puisi 
baru, artinya di luar puisi Sunda lama seperti: pupuh, sisindiran, dan sair. Walau tidak menganut pada aturan puisi Sunda lama, akan tetapi masih tetap menggunakan purwakanti (persajakan). Purwakanti yang digunakan adalah purwakanti laras wekas (rima akhir sama), yaitu a-a-a-a hanya pada bait kedua i-i-i-a.

Fenomena kehidupan malam di kota, dimetaforakan lewat adu jengkerik yang marak dalam kehidupan masyarakat Sunda waktu itu, terutama di kalangan anak-anak. Pesan moral tersebut ingin disampaikan lewat lagu Jangkrik, melalui pesan yang tersembunyi di balik humor yang jenaka. Kesan pertama orang menyenangi lagu ini karena lagunya enak didengar, rancak, semangat. Faktor instrinsik merujuk istilah Sumarjo (2000: 169) atau intraestetik menurut Rohendi Rohidi (2011: 53) seperti dikutif Lalan Ramlan (2013: 43) yang mudah ditangkap oleh audiens, karena terindra melalui medium suara dalam bentuk lagu. Adapun pesan atau nilai ekstrinsik dari lagu tersebut disembunyikan, dan merupakan argumentasi si seniman penciptanya sendiri yang memiliki sifat subjektif (Sumardjo, 2000: 240). Untuk dapat mengerti pesan atau isi dari lagu tersebut dibutuhkan bekal pengetahuan dan pengalaman apresiasi seni, minimal tentang apresiasi seni kawih dan sastra lagu.

Kritik sosial yang disampaikan Mang Koko melalui lagu, mendominasi kekaryaannya pada genre seni sekar jenaka Kanca Indihiang. Kritikan Mang Koko tidak terbatas ditujukan pada masyarakat luas, kalangan birokrat juga tidak luput dari sasarannya, misalnya lagu Badminton, adalah gambaran pelayanan kaum pejabat pada masyarakat. Kok atau bola untuk permainan badminton diibaratkan sebagai rakyat kecil, dan pemainnya adalah para pejabat pelayanan publik. Rakyat kecil yang seharusnya mendapat pelayanan yang bagus dalam pengurusan hal yang berhubungan dengan dokumen negara, malah seperti dipermainkan. Disuruh menghadap meja sana, dari sana menuju meja sini, dan seterusnya seperti bola dalam permainan badminton yang dipukul kesana kemari. Padahal untuk mengikuti permainan tersebut, dibutuhkan modal yang tidak sedikit bagi rakyat kecil yang sehari-harinya juga kekurangan. Tersirat dalam cuplikan teks lagu Badminton berikut.
Kokna ku bulu entog,

Reket pangebug kasur,

Lapang di kebon awi,

Netna samping kebat tutumbuan.

(Koknya pakai bulu itik, Raket pemukul kasur,

Lapangan di kebun bambu,

Netnya kain yang di sambung-sambung.)

Betapa susahnya mengikuti permainan mereka, malah akhirnya di-smes, di-lob ke sana ke mari tanpa hasil yang memuaskan. Akan tetapi pesan tersebut disembunyikan di balik pemilihan idiom kata yang sederhana dan disampaikan dengan jenaka. Pesan atau nilai ekstrinsik dari lagu tersebut tidak dapat dikenali, kalau tidak dicermatinya. Untuk dapat mencermatinya dibutuhkan bekal pengalaman seni yang memadai karena yang disampaikan Mang Koko dalam karya lagunya adalah cermin keinginan masyarakat, gambaran nilai-nilai yang didambakan masyarakat, bukan semata-mata gambaran realitas masyarakat.

Penciptaan lagu-lagu baru dan pengemasan pertunjukan Kanca Indihiang merupakan bukti kerja Mang Koko dalam mengkritisi seni tradisi khususnya seni Jenaka Sunda. Jenaka Sunda yang menonjolkan humor dengan memanfaatkan lagulagu kepesindenan tradisi, diubah menjadi seni humor tematik yang disesuaikan dengan lagu-lagu baru yang diciptakannya. Tidak saja lagunya, waditranya juga digarap berdasarkan pemahamannya atas waditra, terutama kacapi sebagai waditra pokok. Petikan kacapi tradisi diperbaharui dengan petikan-petikan baru yang lebih dinamis sesuai dengan karakter dan jiwa lagunya. Garap waditra, antara kacapi, rebab, dan suling kadang-kadang terjadi dialog dalam suatu komposisi gending. Begitu pula penambahan waditra perkusif yang berbeda-beda untuk tiap lagu, misalnya pada lagu Ronda Malem ditambah kentongan, dalam lagu Beus kota dilengkapi dengan peluit dan terompet balon, dan sebagainya. Lengkaplah bila Mang Koko dijuluki sebagai sang inovator yang memiliki sifat kritis tinggi walau humorisnya tidak ditinggalkan. Sifat-sifat atau karakter tersebut tampak dalam kekaryaan seni dalam grup Kanca Indihiang. 
Itulah sebabnya gaya seni Kanca Indihiang yang dibentuknya dinamakan Sekar Jenaka, karena lagulagunya dibuat dengan konsep estetika seni Sunda modern, walaupun tetap dalam format seni humor.

\section{Penutup}

Inovasi-inovasi garap yang dilakukan pada lagu-lagu sekar jenaka Kanca Indihiang, kemudian lebih dikembangkan lagi pada proses kreativitas Mang Koko pada periode waktu selanjutnya. Munculnya lagu-lgu sekar caturan pada tahun 1950-an yang dimulai dengan lagu Sekar Catur karya Mang Koko, sebetulnya sudah tampak bibitnya pada lagu-lagu gaya dialog dari zaman Kanca Indihiang. Lagu-lagu layeutan swara yang dikembangkan Mang Koko akhirnya menjadi model garap sajian rampak sekar dengan tiga sampai empat tahapan swara, sehingga memunculkan sebutan kawih Mang Kokoan yang populer sejak akhir dekade tahun 1960-an. Pengembangan petikan kacapi kawih yang dimulai dari petikan dijambret, kemudian memunculkan sebutan kacapian Mang Koko yang berbeda dengan petikan kacapi tradisi yang lain. Begitu pula garap aransemen kacapi, lebih diperlebar pada karya-karya zaman Ganda Mekar mulai akhir tahun 1950-an. Bahkan awal tahun 1960, Mang Koko melakukan garap transmedium dari aransemen kacapi ke aransemen gamelan pelog salendro yang populer dengan sebutan gamelan wanda anyar. Konsep garap gending gamelan wanda anyar merupakan aplikasi konsep layeutan swara yang telah dirintis sejak zaman Kanca Indihiang, yang kemudian diterapkan pada waditra gamelan. Dengan demikian, karawitan wanda anyar karya Mang Koko yang populer di tahun 1960 sampai 1970-an sebetulnya berawal dari garapan sekar jenaka Kanca Indihiang yang dimulai tahun 1946. Dengan kata lain bahwa konsep garap karya Kanca Indihiang merupakan embrio dari kreativitas kekaryaan Mang Koko dalam melahirkan karawitan Sunda wanda anyar.

\section{Kepustakaan}

Adisastra, Epe Syafei. 1984. Sastra Lagu Sunda. Bandung: Proyek Pengembangan Institut
Kesenian Indonesia, Sub Proyek Akademi Seni Tari Indonesia Bandung.

Ardjo, Irawati Durban. 2011. 200 Tahun Seni di Bandung. Cetakan Pertama. Bandung: Pusbitari Press.

Irawan, Endah. 2003. "Komparatif Gaya Nyanyian Tiga Orang Sinden Populer Jawa Barat: $\mathrm{Hj}$, Ijah Hadijah, Cicih Cangkurileung, dan Cucu Setiawati" [Tesis] Program Pengkajian Seni Pertunjukan dan Seni Rupa, Universitas Gajah Mada, Yogyakarta.

Koesoemadinata, Rd. Machyar Angga. t.t. Ringkesan Pangawikan Rinenggaswara. Djakarta: Noordhoff- koff N.V.

Koswara, Tatang Benyamin, Ade Setiawan Saripin, M.A. Suratman, Ida Rosida Koswara dan Muadz. 1992. Pembaharu Karawitan Sunda "Mang Koko" (Haji Koko Koswara). Bandung: Yayasan Cangkurileung Pusat.

Kos Warnika, "Mang Koko Maestro Karawitan Sunda”, Part 2, http://www.youtube.com/ watch?v=u7d8XY33jYK, diakses tanggal 9 Desember 2011, 11:05:06

Ramlan, Lalan. 2013. “Jaipongan: Genre Tari Generasi Ketiga dalam Perkembangan Seni Pertunjukan Tari Sunda" dalam Resital Jurnal Seni Pertunjukan Vol. 14 No. 1, Juni 2013, hlm. 41-55.

Rohidi, Tjetjep Rohendi, 2011. Metodologi Penelitian Seni. Semarang: Cipta Prima Nusantara.

Rustandi Mulyana, Aton. 2005. “Gurit Lagu Kawih Sunda” [Tesis] Program Pascasarjana, Sekolah Tinggi Seni Indonesia (STSI) Surakarta.

Ruswandi, Tardi. 2007. Koko Koswara Maestro Karawitan Sunda. Bandung: Kelir.

Setiawan, Hawe. 2004. Sang Komponis Nano S. 60 Tahun. Jakarta: Pustaka Jaya.

Solihin, Asep, 2012. "Sastra Lagu: Teori Ngarumpakaan Lagu dan Ngalaguan Rumpaka". Diktat Kuliah, Jurusan Karawitan Sekolah Tinggi Seni Indonesia (STSI) Bandung.

Soepandi, Atik, 1988. Kamus Istilah Karawitan Sunda. Bandung: Pustaka Buana.

Sudarsono, Tarjo. 1991. "Teknik Olah Vokal Jenaka Sunda Haleuang Rasa”. [Laporan 
Penelitian] Akademi Seni Tari Indonesia (ASTI) Bandung.

Sukanda, Enip, Ma’mur Danasasmita, dan Atik Soepandi. 1985. "Kawih di Priangan" [Laporan Penelitian] Proyek Pengembangan Institut Kesenian Indonesia sub proyek ASTI Bandung.

Sumardjo, Jakob. 2000. Filsafat Seni. Bandung: Penerbit ITB.

Sunarto, Bambang. 2010. "Epistemologi Karawitan
Kontemporer Aloysius Suwardi” [Disertasi] Program Doktor Ilmu Filsafat, Fakultas Filsafat Universitas Gajahmada, Yogakarta. Suryana, Tatang. t.th. "Karawitan Sunda Versi Mang Koko" [Manuskrip].

Waridi. 2005. “Tiga Pilar Kehidupan Karawitan Jawa Gaya Surakarta Masa Pascakemerdekaan Periode 1950-1970-an” [Disertasi] Program Pengkajian Seni Pertunjukan dan Seni Rupa, Universitas Gajah Mada Yogyakarta. 